\title{
The impact of norms on political decision-making: How to account for the European Parliament's Empowerment in EU External Trade Policy
}

\section{Guri Rosén}

\begin{abstract}
The Lisbon Treaty gave the European Parliament (EP) considerable new powers in the field of external trade policy. This is puzzling as there is little to support dominant explanations such as bargaining on the part of the EP or member states making it a priority to enhance the EP's role in trade. The article shows how the EP (together with the Commission) was able to convince the Convention that extending the EP's trade powers was reasonable because there were no valid arguments for exempting trade from the general rule of linking QMV and codecision. The findings challenge established accounts of the EP's empowerment by demonstrating how the principle of parliamentary representation is not an uncontested source of legitimacy, despite its constitutional status. In situations where institutional foundations are debated, even the principle of parliamentary representation may be put to the test. The article also adds to the debate about the role of norms in political decision-making, by focusing on mutual acceptability rather than truth-seeking as the key coordinating mechanism of arguing, clarifying its relevance to the study of political processes.
\end{abstract}

Key words: Decision-making mechanisms, EU external trade policy European integration, European Parliament, Interinstitutional relations 


\section{Introduction}

In July 2012, the European Parliament (EP) rejected the Anti-Counterfeiting Trade Agreement (ACTA). This was the first time the EP vetoed an international trade agreement, a right it obtained in the Lisbon Treaty. Up to this point, the dominant stance in the European Union (EU) seems to have been that "external trade policy is best conducted without any parliamentary input or interference' (Krajewski 2005: 97). Traditionally a realm of national and European technocrats, 'every movement in the direction of increased legitimacy would, supposedly, reduce the margin of manoeuvre of negotiators and impede their ability to conclude complex international agreements' (Meunier 2003: 75). The Council had been 'extremely reluctant to allow the EP into its bilateral game with the Commission' (Vanhoonacker 2011: 82), and at the Nice IGC, no member state delegations supported efforts to increase the EP's trade powers (Krenzler and Pitschas 2001: 312). It is surprising therefore that, only a few years later, the European Convention granted the EP legislative powers over trade policy as well as consent power over international trade agreements.

This decision is also puzzling from a theoretical perspective because prominent explanations for the empowerment of the EP do not appear to fit the data. Benedetto and Hix (2007) have claimed that the success of the EP's proposals during the Convention was to a large extent determined by the level of backing by member states. However, there is little to support that member states made it a priority to enhance the EP's role in trade. Convention documents and plenary debates show that whereas MEPs advocated an empowerment of the EP in trade, member states rarely brought it up. Another prominent explanation of EP-empowerment is that the Parliament itself is able to force concessions from the member states by linking legislative decisions across time or policy area (e.g. Farrell and Héritier 2003). Norman (2003) has 
described how MEPs, at the end of the Convention process raised a series of demands in return for compromise on other issues, together with national parliamentarians. Still, there is no evidence of issue-linkage between negotiations on trade and other ongoing policy processes, neither in Brussels nor in the Convention. How then, can the EP's empowerment in EU external trade policy be explained?

In their study of the introduction of codecision in agriculture, Roederer-Rynning and Schimmelfennig (2013) argue that "[c]odecision was introduced as a matter of principle following a constitutional template for the EU polity" (2013: 965). This suggests that the EP's empowerment is conditioned by the normative context of the decision-making process. Some authors have also claimed that demands for more democracy led to parliamentary empowerment in trade, but without substantiating the claim further (van den Putte et al. 2014, Vanhoonacker 2011). Given that explanations based on material factors do not fit the empirical pattern in the case of trade, and that other studies have highlighted the impact of democratic concerns, the starting point for this article is that normative considerations affected the decision to give the EP new powers over EU trade policy. Thus, the question that this article sets out to answer is: which norm-based explanation best accounts for the EP's increase in trade powers?

Several authors have argued that in order to properly understand the empowerment of the EP, one has to look at the role of norms. Pooling and delegating national sovereignty to the supranational level triggers concerns about a legitimacy deficit, leading to a series of decisions to enhance the powers of the EP (Rittberger 2005). These developments are said to amount to a process of constitutionalisation, where the principle of representative parliamentary democracy has become 'embedded in the 
EU's legal order' (Rittberger and Schimmelfennig 2006: 1149). But while an increasing number of studies agree on the need for norm-based explanations to account for the empowerment of the EP, different driving forces have been put forward: One is that the extension of the EP's powers is a habitual response to the legitimacy deficit caused by the delegation of national competences to the EU-level (Goetze and Rittberger 2010, Rittberger 2012). Another explanation is that member states empower the EP because they become "rhetorically entrapped" and do not want to suffer the costs of advocating a position that may be perceived as illegitimate (Rittberger and Schimmelfennig 2006). Finally, the EP's empowerment has been depicted as a process of contestation and politicization as well as one of 'accepting sometimes overtly and at other times more tacitly - democratic arrangements' (Eriksen and Fossum 2012: 332).

Trade is an area where the EP had very limited powers prior to the Convention process, and therefore it provides a good case for testing different explanations for EP empowerment. There was no informal presedence for including the EP in decisions on trade implementing regulations before codecision was introduced in the Lisbon Treaty, which means that the agreement to increase the EP's powers was reached during the Convention. It was also one of few areas where QMV was used extensively without codecision. In addition, arguments used against extending the EP's powers in trade resembled those used in foreign policy in general (Woolcock 2008), which makes it a tough case for normative explanations. These aspects make trade a suitable case to improve analytical precision and develop the existing theory on how normative considerations have impacted EP empowerment.

\section{How to explain the increase in the EP's external trade powers?}


Before Lisbon, EU trade policy was run by executive actors, according to Article 133 (TEC), and did not foresee any involvement of the EP. Thus, the Lisbon Treaty brought a small revolution to the area of trade. Firstly, trade policy regulations are now subject to the codecision procedure. Secondly, a corollary to the introduction of codecision is that the EP's consent to trade agreements is necessary. (1) As a result, the EP now has both legislative and veto powers in trade policy. Thirdly, the Commission must report regularly to the EP about international trade negotiations.

Roederer-Rynning and Schimmelfennig (2013: 965) contend that the introduction of codecison followed a constitutional template. However, the constitutional logic they describe is 'macro-institutional' (ibid.: 956), and thus not at the same level as the other explanatory mechanisms investigated in this article, which focus on the agency level. Although they present a convincing analysis, one is left with the question of why this constitutional template succeeded in trumping other concerns. This article concentrates on three main accounts that offer a norm-based explanation of the EP's empowerment: habitual response, rhetorical entrapment, and reason-giving.

\subsection{Habitual response}

Goetze and Rittberger (2010: 38) have argued that after Maastricht, the 'principle of involving the EP (...) in the EU's decision-making structures' has scarcely been contested. The EP's role 'in providing democratic legitimacy has become (largely) unquestioned by political elites' (Goetze and Rittberger 2010: 50) and it is taken-forgranted that whenever there is a deepening of integration through the extension of Qualified Majority Voting (QMV), codecision is also introduced (Rittberger 2012). The mechanism of 'taken-for-grantedness' is based on sociological institutionalist theory where action is understood as 'scripted' - shaped by culture through schematic 
cognition. Norms, such as the principle of parliamentary representation in the EU, that have acquired legitimacy are increasingly taken-for-granted. Legitimacy is held to be an 'inter-subjective property', located in 'individual perceptions regarding the object's conformity to the cultural beliefs of its audience' (Goetze and Rittberger 2010: 39ff).

Thus, Goetze and Rittberger (2010: 41) see the empowerment of the EP as a habitual response 'reflecting actors' conceptions of the appropriate or "natural way" of supplementing political authority with popular sovereignty'. After being instituted in the Single European Act in 1986, the link between QMV and codecision could no longer be contested because it represented the solution to the legitimacy deficit created by the delegation of authority to the EU-level (Rittberger 2005: 181ff). Rittberger (2012: 21ff) has argued that the institutionalisation of the principle of parliamentary representation has reached a stage where institutional choice, such as the extension of the legislative procedure to new policy areas, is determined by takenfor-granted assumptions, shared cultural understandings and institutional isomorphism. So whenever QMV is extended to new issue areas, an undisputed acceptance of the need to also introduce codecision is to be expected (Rittberger 2012: 31-33). As the Lisbon treaty extended the EU's trade competences by subjecting more of the field to QMV and introduced codecision, one might thus assume that the EP's powers were increased due to the taken-for-granted status of the principle of "no integration without representation".

What would one expect to see empirically if a taken-for-granted status of the EP as a colegislator could explain the increase of its powers in external trade? Goetze and Rittberger (2010: 42) argue that low levels of legitimacy means that actors have to 
justify their behaviour, while when levels of legitimacy are high, justifications are not required. Scarcely any articulation should in fact be needed (Rittberger 2012: 32). From this, one can infer the following observable implications: That the increase in EP's trade powers was not contested and that actors involved in the Convention proceedings did not need to justify their claim to empower the EP. Moreover, one would expect actors to introduce codecision automatically when decisions are made to extend QMV.

Sociological institutionalism see rules as self-enforcing 'because actors have internalized the belief that some actions are appropriate, natural and legitimate' (Olsen 2009: 10). An alternative take on how norms shape behaviour and collective action is that references to normative principles during negotiations are rhetorical utterances motivated by strategic aims. Following a rhetorical action approach then, norms are used, not followed (Schimmelfennig 2003: 194).

\subsection{Rhetorical action}

Rittberger and Schimmelfennig (2006: 1150) have argued that the development of the EP's powers should be understood as a result of 'strategic action in a community environment'. Member States may bargain over the EP's appropriate role in specific cases and the EP's own efforts may have contributed in developing its powers, but these explanations do not capture the general mechanism driving the process of parliamentarisation in the EU. Instead, the EP's empowerment is generated by actors who shame their opponents into complying with the identity and principles of the EU (Rittberger and Schimmelfennig 2006). The EU is a tight knit community and its member states are committed to liberal democratic values. As a result, the norms that constitute the Union's community environment can be exploited through rhetorical 
action (Rittberger 2005, Rittberger and Schimmelfennig 2006). Because illegitimate actions are costly and actors are concerned with their image, they will act in accordance with the norms in question even when it is against their interests. A mechanism of self-restraint leads actors to change their behaviour in accordance with prevailing norms. (2) A prerequisite for rhetorical entrapment is prior rhetorical commitment, because of the potential it provides for exposing inconsistency between talk and walk (cf. Schimmelfennig 2001). Following from this perspective, the hypothesis would be that the EP's opponents, faced with a naming and shaming strategy, would change their position because they were concerned with the potential costs of refusing an increase of the EP's trade powers.

If a rhetorical strategy were pursued during the Convention, one would expect actors to link their demands for more EP powers to established EU norms and practices in order to name and shame their opponents. Because rhetorical action may compensate for a lack of bargaining powers, one would expect this strategy to be particularly popular among actors with little material leverage such as smaller member states or the EP. If this strategy were successful, one would expect actors who go from not supporting to supporting an increase in the EP's trade powers to be concerned that opposing the EP's empowerment be perceived as illegimate. Finally, one would expect the reason they give for their change of position to vary across contexts and that they may try to modify or reverse the decision at a later stage.

According to the rhetorical action approach, actors 'will not change their identities and norms or learn and internalize new, "appropriate" preferences as a result of their interaction in the EU context' (Rittberger and Schimmelfennig 2006). A different way of conceiving of the impact of norms is that actors choose to behave according to 
norms when they are perceived to be valid, and not because neglecting them would be costly.

\subsection{Communicative approach}

Building on communicative action theory, Eriksen and Fossum (2012: 332) have portrayed the development of the EP's powers as a process of contestation and politicization as well as one of 'accepting - sometimes overtly and at other times more tacitly - democratic arrangements'. (3) Eriksen and Fossum argue that while the parliamentarisation of the EU is inspired by the representative democracies of its member states, there is no direct transfer of principles from the national to the EU level. Because democracy at a supranational level is contested, 'a key challenge for the EU has been to come up with convincing justifications for explaining which democratic norms are applicable to its unique setting' (2012: 331). As a result, in order for norms to have an effect on decision-making and hence the decision to empower the EP, 'they need to be interpreted, communicated, recognized, and converted into action schemes by means of agents' collective efforts' (ibid.).

Communicative theory is based on the assumption that if convinced by a valid argument, actors may change their behaviour accordingly (Habermas 1996). Norms that in principle are universally acceptable are more likely to be perceived as valid, which means that actors are expected to 'seek to link negotiations to principles and norms that lend themselves to universality' (Deitelhoff 2009: 45). The communicative approach directs the focus on how norms are activated and assessed during decisionmaking processes. When there is disagreement over how to understand, or how to apply norms, there is also less certainty about which norms to follow and why (Eriksen 1999, Sjursen 2002). As a consequence, actors enter into a 'conscious 
process' where they 'have to figure out the situation in which they act, apply the appropriate norms, or choose among conflicting rules' (Risse 2000: 6). The action coordinating mechanism is mutual acceptance. This leads to the hypothesis that the increase in EP's trade powers was triggered by acceptable arguments that led opponents to change their positions.

Indicators that the increase in EP's trade powers were a result of communicative interaction would be: That actors argued according to generalized standards. If these justifications were accepted as valid, decision-makers would refer to these arguments when conceding to extend the EP's trade powers and in justifying a change in their own position. Finally, verbal commitments and subsequent behaviour have to be consistent. If an actor supported an extension of the EP's powers in the Convention but tried to stop it at the following IGCs, it would not be in accordance with a communicative explanation.

The three hypotheses and corresponding empirical expectations are summarised in the table below.

Table 1. Hypotheses and empirical expectations

\begin{tabular}{|l|l|l|}
\hline Explanations for the & Hypotheses & Empirical \\
trade & expectations \\
\hline & increased because the & by little or no conflict \\
principle of & parliamentary & - actors did not justify/ \\
Habitual response & representation was & positions \\
\hline
\end{tabular}




\begin{tabular}{|c|c|c|}
\hline & taken-for-granted. & $\begin{array}{l}\text { - automatic } \\
\text { introduction of } \\
\text { codecision if QMV is } \\
\text { extended. }\end{array}$ \\
\hline Rhetorical entrapment & $\begin{array}{l}\text { The EP's powers were } \\
\text { increased because } \\
\text { opponents were } \\
\text { rhetorically entrapped. }\end{array}$ & $\begin{array}{l}\text { - prior commitment to } \\
\text { enhance the role of the } \\
\text { EP } \\
\text { - naming and shaming } \\
\text { of opponents to } \\
\text { empower the EP } \\
\text { - fear of the potential } \\
\text { costs of denying an } \\
\text { increase in the EP's } \\
\text { powers } \\
\text { - opponents alternating } \\
\text { arguments according to } \\
\text { context }\end{array}$ \\
\hline $\begin{array}{l}\text { Communicative } \\
\text { perspective }\end{array}$ & $\begin{array}{l}\text { The EP's powers were } \\
\text { increased because } \\
\text { opponents accepted } \\
\text { arguments for } \\
\text { empowerment as valid. }\end{array}$ & $\begin{array}{l}\text { - debate characterised } \\
\text { by argumentation } \\
\text { according to } \\
\text { generalized standards } \\
\text { - change in position } \\
\text { justified with reference } \\
\text { to valid argumentation. } \\
\text { - consistent use of } \\
\text { arguments across } \\
\text { settings and time }\end{array}$ \\
\hline
\end{tabular}

\section{Analysis}


To identify the mechanisms that led to the empowerment of the EP in trade, I have used process-tracing methodology. All three explanations described above suggest how normative considerations may have led to an increase in the EP's trade powers. Faced with equifinality, the goal is to find out which of the potential normative mechanisms can best account for this outcome. I have chosen to focus on the most central aspects of the mechanism in operationalising the explanations because this is key to differentiating between them (cf. Schimmelfennig 2014). In recreating the process of empowering the EP in trade, I looked for the observable implications of the hypotheses described above (Bennett and Checkel 2014). The article reconstruct the actions, positions and arguments of the decision-making processes. Furthermore, I focused on the interaction between the actors that took part in decision-making, and the reasons they give for their actions and positions. Accounts given by different actors were checked against each other to control for the possibility that one actor gave a different set of reasons for the outcome than others.

The data consist of official EU documents that address the EP's role in trade: EP plenary debates, reports and minutes, Commission and Council documents. In addition, documents from the Convention process and the ensuing IGCs have been analysed, and the data has been complemented by secondary literature. (4) I have conducted 17 interviews with politicians and officials from the EP (7), the Commission (3), the Council secretariat (3) and representatives from the Member States, the most of which came from member states that were sceptical to EP empowerment in trade (4). Several interviewees took part in the negotiations in the Convention or were close observers. The majority of them have also been working on trade for many years. The interviews were conducted between 2011 and 2015. (5) 


\subsection{Automatic agreement?}

If the empowerment of the EP in trade were taken-for-granted, one would expect to see a debate characterised by little conflict and actors maybe stating their positions, but not justifying them. Also, if QMV is extended, codecision should automatically follow suit.

Initially, the EP's role in trade did not trigger much dispute in the Convention. Documents show that during debates in the Working Group (WG) on External Action the role of the EP was hardly raised, and in the WG's preliminary draft report it is not explicitly mentioned (Working Group VII 2002b).(6) Several interviewees also reported a low level of attention to the issue during the early working group meetings. Similarly, it did not spur a wide debate in the Convention plenary on the early instances where external action was on the agenda. Although this would appear to corroborate the notion that the EP was taken-for-granted as a colegislator in trade, there are several reasons why the explanation does not fit the empirical picture.

When claims for the extension of EP's powers were presented, they were explicitly justified. In an intervention in the WG on External Relations, Pascal Lamy, then Commissioner for Trade, made the case that excluding the EP weakened the legitimacy of EU trade policy, and that letting the EP participate in decision-making would increase its accountability (WG VII 2002a). During the debate on the WG's final report, several MEPs advocated extending the EP's role in trade using similar arguments. Their claims were justified with reference to the need to reinforce democratic legitimacy in EU trade policy and the consistency of institutional arrangements (verbatim records, 20.12.02). (7) This is not what one would expect if the EP's role in trade were extended as a matter of habit. The presentation of justified 
arguments in itself does not necessarily undermine the notion of habitual adaption. However, the debate also reflects that the norms supposed to guide decision-making were contested, which indicates the lack of an established action script. By contrast, this was an unsettled issue that required actors to justify their claims for change. This weakens the likelihood that the EP was empowered because actors took for granted that it was the appropriate thing to do.

Although some interviewees emphasised a lack of heated debate about the EP's role in trade, the details of the process tells a somewhat different story. Diverging positions among the conventioneers are reflected in the work of the WG on External Relations. In its first draft of the final report, the EP's role in trade was not mentioned (WG VII 2002b). The first revision demonstrates that the members of the working group had different positions. It incorporated both an amendment put forward by UK government representative, Peter Hain, that 'some members believed that changing the current arrangements could have unwelcome effects on the distribution of internal competences within the EU'. At the request of a group of parliamentarians, it also stated: 'Other members considered that QMV and co-decision should apply to all trade matters and more generally to all external aspects of internal policies where QMV applied.' (WG VII 2002e: 15). In the third revision, however, the reference to codecision had been removed and replaced with 'some members considered that the involvement of the EP should be enhanced' (WG VII 2002f: 27). Still, the EP was not without its supporters, and in the final report 'some' had become 'several' (CONV 459/02: 8). Nevertheless, it demonstrates that the link between QMV and codecision was not automatically established in the area of trade. By contrast, when the WG on Simplification recommended that QMV and codecision be the norm for legislative decision-making, it 'transformed the debate over the group's report from the technical 
to the political' (Norman 2003: 102). This defies the expectations of a habitual response-explanation, because a key indicator is that actors will automatically introduce codecision when QMV is extended.

The above analysis shows that the EP's empowerment is still being questioned, and therefore contradicts the conclusion that 'the principle of EP co-legislation assumed a taken-for granted status' during the Convention process (Rittberger 2012: 32). Despite the constitutional status of the principle of parliamentary representation (Rittberger and Schimmelfennig 2006), it still has to be defended. The EP's empowerment in trade was closely linked to varying views on what the EU is, and should be, which shows that even constitutional principles may be up for discussion when raised on the basis of other competing foundational principles. Based on these findings, it is also reasonable to question whether institutional choices that equal constitutional choices will be subsumed under the logic of habitual response.

The conventioneers advocating EP consent over international trade agreements were not in a majority in the working groups, and several of those supporting an extension of the EP's role in trade envisioned consultation rather than codecision (Krajewski 2005). In the words of one interviewee, it was not the case that everybody was in favour of a change in the EP's role (NAT\#3). Thus, it was never self-evident that the EP would increase its powers in trade. As a consequence, the empowerment of the EP in trade requires another explanation. It would for instance be plausible to assume that once the issue hit the plenary, there would be even more room for naming and shaming strategies, strengthening the claims of the European Parliament.

\subsection{Rhetorical entrapment?}


If the empowerment of the EP in trade were a result of rhetorical entrapment, one would first of all expect that there had been a prior commitment to extend the role of the EP. Secondly, that advocates evoked the principles of the "community environment" to up the leverage of their demands, and finally, that the opponents of empowering the EP took steps to avoid being "shamed", or were "silenced".

There cleary were normative commitments to increase the powers of the EP in general before the Convention. The Laeken Declaration stated that a key goal of the upcoming treaty revision process was to increase the democratic legitimacy of the EU institutions (European Council 2001). This gave a potential opener for member state governments for lack of consistency. However, there are few signs of MEPs, or other actors, trying to name and shame those who wanted to retain the status quo. According to interviewees from the EP, their strategy was to avoid bringing the trade issue to the public's attention (EP\#3). 'We never steered it, you know, publicly, we never fought about it publicly, I think it was the right strategy' (EP\#1). At the same time, MEPs tried to deflect member states with other issues: 'I recall distinctly on purpose accentuating the argument on the things we didn't get our way on (...) in order to eat up the time that would otherwise have spilled over into a discussion on ordinary trade.' (EP\#3).

But the decision to increase the EP's trade powers cannot be properly explained only by looking at the Convention debates on trade-specific issues. When advocating for enhanced powers in trade, MEPs mainly argued according to generalised principles, instead of policy-specific ones (EP\#1, EP\#3, NAT\#3, NAT\#4). Increasing the EP's powers was justified with reference to the need for democratic anchoring of trade policy, but also with reference to the need for institutional consistency. Thus, the EP 
may have practiced naming and shaming during debates on general institutional principles also applicable to trade. However, there are few signs of that either. In other words, the EP - which is the likely candidate for choosing such a tactic, did not aim at strategically exposing their opponents' breach of community norms.

But the absence of naming and shaming in itself does not preclude the possibility that actors may have felt rhetorically entrapped. The Laeken Declaration was commited to address the EU's democratic challenges and a main ambition of the Convention was to simplify the EU's legal framework. In the final report of the WG on Simplification, general effect was given to the principle that areas subjected to QMV should also be subjected to codecision. An important rationale for this suggestion was the need to make policy-making processes more transparent and intelligible, and hence more democratic (CONV 424/02). During plenary debates, numerous interventions concerning codecision were justified with reference to the equal importance of the EP and the Council as legislators and to the democratic legitimacy of decision-making procedures. Against this background, actors could have chosen to stay silent because they anticipated accusations of illegitimate behaviour if they voiced opposition to empowering the EP (cf. Schimmelfennig 2001: 66). If this were the case, one would expect actors to be concerned about their appearance in the Convention.

Several interviewees did emphasise that conventioneers were hesitant to argue against the EP's involvement in trade policy, but a look at the debates shows that diverging opinions on how exactly the EP should be involved were not bottled-up. Some countries were particularly concerned that an increased role for the EP would make international trade agreements even harder to achieve (NAT\#2). In the WG on External Relations, Finland and Sweden raised their worries that involving the EP 
would lead to a more protectionist trade policy (COM\#2). Moreover, the Irish government representative argued that involving the EP should 'reflect the existing balance and competences between the institutions of the Union' (WG VII 2002c). As mentioned above, Peter Hain (UK) made a similar argument, and in a plenary session put forward that, "it should be possible (...) to recognise a greater role for the European Parliament without constraining the legitimate commercial activities of the Member States or undermining the efficiency of the Union' (verbatim, 16.05.03). Because codecision was deemed impractical and too time-consuming, the British solution was to replace codecision with consultation. (8) Finnish government representatives also put forward a similar argument in writing. (9) Their message was echoed in the plenary by a Finnish MP, who maintained that the provisions on trade in the Nice Treaty should be preserved (verbatim, 04.07.03).

If conventioneers felt forced to comply with the norm of QMV and codecision, one would expect them to be less outspoken about exceptions and reservations. Although support for extending the EP's legislative powers was prevalent, there was still a discussion about how to strike the right balance between differing principles, for instance between the need for more democratic procedures at the EU-level versus concerns for national sovereignty. (10) While most conventioneers agreed that the EP's powers had to be strengthened, there was also a discussion about whether all policy areas that were subject to QMV should also be subject to codecision. Members of the Convention who opposed 'an absolute connection between decisions made with QMV and codecision' (Swedish government representative, verbatim, 20.01.03) took issue with the scope of codecision and which, if any, policy areas should be exempt from the general procedure. In the words of one interviewee, everyone knew that there would be exceptions and that this would be a matter of negotiation (NAT\#3). It 
did not come as a surprise that some members of the Convention expressed their disagreement and that debates with some government representatives had to take place (EP\#7).

Finally, if it were the case that member states had been rhetorically entrapped, one would expect them to raise the matter once the debate moved behind closed doors during the ensuing IGCs. Nothing in the interviews, documents, or existing literature suggests that this was the case. As the extension of codecision was not questioned further in the following IGCs (Bürgin 2007), there is no evidence that the actors changed their line of argumentation. Taken together, there are few signs that opponents to empowering EP in trade were rhetorically entrapped. Naming and shaming was not a strategy employed by the EP or its supporters, and to conclude that actors were effectively silenced, one should at least see signs that they were mindful of the costs of illegitimate actions. The fact that there were several discussions about the scope of codecision weakens the impression that conventioneers felt forced to comply with the "community ethos". It is worth considering whether the "Convention ethos" weakened the potential silencing effect. Under different circumstances arguing counter to shared legitimacy standards would have been precarious because it damages one's credibility as a negotiation partner (Rittberger and Schimmelfennig 2006); but because this was a "constitutional moment" where arguing was encouraged, it may have been less risky.

However, the increase of the EP's trade powers still needs to be accounted for. In the case of trade, the concern for national sovereignty has traditionally been a guiding norm, keeping the EP's role a marginal one (Woolcock 2008). Instead, if the norm of including the EP has taken hold, one could argue that a theoretical perspective is 
needed that can account for why certain norms or principles are considered valid in the first place (cf. Sjursen 2002: 500).

\subsection{Arguments accepted as valid?}

If the empowerment of the EP were a result of mutual acceptance of the arguments favouring increasing parliamentary trade powers, one would expect to see that actors advocating an extension of the EP's role refer to general principles. Subsequently, if recalcitrant actors accepted these justifications as valid, they should justify a change in position with reference to similar principles. Finally, verbal commitments should be consistent with behaviour across settings and time.

After the Nice Treaty, the EP argued that its own involvement in trade policy was a democratic necessity, given that the role of national parliaments was waning (European Parliament 2001). During the Convention, empowering the role of the EP in trade was justified in a similar manner. The process in the WG External Relations shows that these arguments made an impact. In the first preliminary draft report of the WG the EP was not mentioned (WG VII 2002b), this then changed in the third draft where 'some members' supported a greater role for the EP in trade (WG VII 2002e), and in the final report 'several members' expressed support (CONV 459/02). The final report also referred to the conclusions of the WG on Legal Personality, which maintained that it was difficult to justify, at a political level, why the EP should be denied consultation on international agreements (CONV 305/02). Interviewees report that there was a growing impression in the WG that without an extension of the powers of the EP, trade agreements would escape parliamentary scrutiny they would have had in (some) member states, which would leave a gap (EP\#3). Most of the 
members of the working group then agreed that there was a need to change how trade was governed to make it more democratic (NAT\#3).

These developments resonate with arguments put forward by Commissioner Lamy, a handful of other members of the WG on External Relations, and MEPs who stressed that the involvement of the EP did not "correspond to the needs of a democratic legitimisation' (CONV 362/02). Prior to the publication of the final report, some also brought up the lack of democratic control of trade policy in the plenary (verbatim, 05.-06.12.02). Thus, the move from no mention of the EP's role to 'several' supporting more involvement indicates that the argument of a need for parliamentary participation in trade to amend its legitimacy deficit had been taken on board. Although British government representative Peter Hain initially had expressed concerns about any increase of the involvement of the EP, in his suggested amendments to the first draft of the treaty articles on external relations, he stated: 'we support the intention to give the European Parliament a greater role'. (11)

Thus, arguments referring to a lack of democratic legitimacy in EU trade policy made decision-makers consider a greater involvement of the EP. This corroborates the indicator that change in position is justified with reference to argumentation acknowledged as valid. However, the introduction of codecision and consent to international trade agreements is still unaccounted for. The final report of the WG External Relations made no mention of codecision, even though a majority in the group wanted to introduce QMV in areas of trade policy where the EU had exclusive competence. Many of those supporting increased involvement of the EP were in favour of consultation, not codecision (Krajewski 2005). As Jacobs (2003: 17) commented, while there was support in the WG Legal Personality to consult the EP 
on trade agreements, he deemed that 'achieving EP assent on such agreements would be more difficult, despite it having some support within the Convention'. (12) MEPs Andrew Duff and Elmar Brok both voiced their dissatisfaction that this WG had not been willing to consider the introduction of the consent procedure (verbatim, 11.10.02)

Looking at the ensuing process, key to gaining traction for codecision in trade was to link it to the wider debate about democracy in the EU. According to one interviewee, the MEPs mostly did not address trade as a singular issue, but saw to it that trade was dealt with in the context of the EP's general legislative powers (NAT\#4). In this effort, the EP gained support from the Commission (Rosén 2016). The Commission had tried to push through a greater role for the EP at Nice, but had not suceeded (COM\#2). At the Convention, according to Lamy (2004), '[t]he objectives were the same, but allies - notably the European Parliamentarians - were more numerous'. Niemann (2011: 36) quotes one interviewee stating: 'the representatives from the European Parliament and the Commission acting united during the Convention on the trade policy issue definitely contributed to changing positions by other Conventioneers'. Both the EP and the Commission were well represented in the WG on Simplification that dealt with general institutional and procedural questions (13), and where a key effort was made to secure that trade was treated under the same umbrella as other areas of Community policy. One interviewee even described the EP's new powers in trade as a 'democratic coup d'ètat' conducted by the EP and the Commission (EP\#4).

Together, they argued for an extension of the EP's role in trade 'but always under the heading, we want to generalise procedures, we want to generalise interinstitutional relations' (EP\#4). The response from the Council's Legal Service was allegedly: 'Yes, 
if you want to have a simplification and if you want to have this in a constitutional way - everything should be done in the same way' (EP\#4). The drafters of the new trade provisions then introduced the link between QMV and codecision in trade as well, following the conclusions on the WG on Simplification (COM\#2). This gives one indication that the argument for consistency had been accepted as valid, leading to an incorporation of trade into the general framework of simplification. By contrast, several MEPs also wanted to introduce parliamentary authorisation of negotiation directives. These claims were allegedly met with the counterargument that 'you don't have that in other fields where there is codecision already' (COM\#2).

Thus, the increase of the EP's trade powers became part of the larger project of democratizing the EU. Comparing statements at different stages of the Convention process shows how the norm linking QMV to codecision gained hold. In January 2003, Germany and France published a joint paper proposing that QMV was to be automatically connected with codecision (CONV 489/03). About a month later, the Spanish and British governments countered that they envisioned the extension of codecision ‘into some new areas', but not an automatic link with QMV (Bürgin 2007: 142-143). Towards the end stages of the Convention, Peter Hain, the UK government representative stated: 'All agree that QMV and codecision should be the norm in this new Constitutional Treaty', albeit with some exceptions (verbatim, 31.05.03). Compared to how the British government described its initial position - 'instinctly doubtful about increases in EP powers' (Commission 2003) - a shift had taken place. The difference between these statements suggests that the acknowledgement of a link between QMV and codecision was a product of the Convention process. 
Although there was broad support for the principle of enhancing the role of the EP, there was less agreement about what this should entail in practice. The WG on Simplification concluded that codecision should be the general rule for the adoption of legislative acts, but added that exceptions would remain in areas of 'great political sensitivity for the Member States' (CONV 424/02). This generated a debate about which policy areas were sensitive enough to be exempted from codecision. Many conventioneers were adamant that the new treaty should not provide for exceptions from the general rule of the legislative procedure, while others contended that there would have to be clear criteria for exceptions (CONV 609/03). This call for explicit criteria was left largely unrequited, but a distinct pattern can be identified. It was difficult to find valid arguments against the introduction of codecision in areas subject to QMV. Even countries essentially sceptical towards the EP accepted that it has a role to play in supranational matters (NAT\#2). By contrast, areas that were under unanimity rules did not suffer an obvious legitimacy deficit nor could it be argued that QMV should be extended for reasons of consistency (Bürgin 2007: 151). Looking at the debate about the EP's role in CFSP, for instance, several contested empowerment with reference to the role of national parliaments (verbatim, 11.07.02).

In their study of the introduction of codecision in agriculture, Roederer-Rynning and Schimmelfennig showed that "vested interests fought to protect intergovernmental control in this area' (2013: 964). However, arguments for maintaining the status quo did not resonate with the majority of Convention members. Following MEP Duff, whoever wanted exceptions from the legislative procedure were obliged to justify and specify the reasons for excluding the EP: '[S]olely to safeguard classical interests (...) is not sufficient for me to be convinced that Parliament should be excluded (verbatim records, 17.03.03)'. Roederer-Rynning and Schimmelfennig conclude that agriculture 
'had to fall in line with the principles of legal rationalization and representative democracy that produced a general thrust towards codecision' (2013: 965). Still, the question why the constitutional template trumped competing concerns is left open.

Niemann (2011: 35) cites an interviewee stating: 'External trade was the only policy area in which the European Parliament had hardly any role. Given the Laeken declaration's emphasis on legitimacy, the EP's claim became even more convincing'. Those opposed to introducing codecision to trade now had to explain why (COM\#2), and as the quote by MEP Duff demonstrates, their arguments had to be acceptable to make an impact. Other interviewees who described the discussions of the WG External Relations as very open corroborate this, and that people tried to find the proper arguments for their positions (NAT\#3). Moreover, being able to give good reasons for one's opinion was key to success in the Praesidium, where the general line of codecision in areas of QMV received wide support (EP\#7). In other words, the 'burden of proof was reversed in that the Member States had to argue against increased parliamentary scrutiny of EU trade policy' (Woolcock 2008: 2). Thus, although some member states wanted consultation rather than codecision, because the principle of parliamentary representation became accepted as a main premise in the debate about democratizing the EU, it was difficult to justify why trade should not follow the pattern of QMV and codecision. One interviewee argued that the Convention exposed a fundamental inconsistency: 'Why would you not have the Parliament and the Council on equal footing which is the rule elsewhere? Basically you should put the charge of the evidence on why you do not have that. And there was no evidence' (COM\#1). In other words, because trade agreements would likely influence EU legislation, it was logical to have codecision in trade as well (EP\#7). Thus, the extension of the EP's trade powers was perceived as unavoidable because of 
the general wish to increase the democracy of EU policies, which meant that the EP would gain more powers in all essential policy areas (NAT\#1). This suggests that conventioneers came to accept that the introduction of codecision in trade was reasonable.

\section{Concluding discussion}

The findings of this article challenge the argument that 'the principle of EP colegislation assumed a taken-for granted status' during the Convention process (Rittberger 2012: 32). Moreover, the analysis contradicts the claim that a 'rhetoric of simplification' was prevalent but with limited practical impact (Magnette and Nicolaïdis 2004: 396). Instead it corroborates Roederer-Rynning and Schimmelfennig's (2013) contention that the introduction of codecision followed a constitutional template. The article has demonstrated how, in the Convention, the extension of the EP's trade powers became embedded in the general discussion about its legislative role in a more democratic EU. However, it also takes a step further by trying to identify the mechanisms behind the application of the general principles. It is argued that the EP (together with the Commission) was able to convince the other members of the Convention that extending the EP's trade powers was reasonable because there were no valid arguments for exempting trade from the general rule of linking QMV and codecision.

Based on the findings in this article, three theoretical implications should be underlined. First of all, the analysis challenges the existing literature on the empowerment of the EP. Rhetorical action and habitual response-explanations have become prevalent in accounting for the development of the EP's powers. No doubt, studies using these approaches have contributed greatly to our understanding of why 
member states have agreed to transfer power to an institution over which they have little, if any, control. However, I would argue that both approaches go too far in assuming that the "community ethos" is uncontested. What this article demonstrates, is that constitutional principles may also be disputed - and perhaps particularly during "constitutional moments" - when they have to be activated and justified in order to prevail. When there is no consensus about a norm set, it is reasonable to assume that it would become more difficult for actors to use norms strategically. Moreover, it is difficult to explain why actors follow habit when it is less clear which rules they should obey. A communicative approach offers an explanation for why principles succeed in circumstances where norms are contested, because it focuses on the process through which norms are activated, scrutinised and come to be considered as mutually acceptable or not (Eriksen 1999, Sjursen 2002).

Secondly, there is a tendency to categorize normative argumentation as either rhetorical or communicative without providing evidence for why it is one or the other. This article offers a plausible way of studying normative mechanisms in practice, which is claimed to be particularly lacking among studies that use the communicative approach for empirical purposes (Schneiderhan and Khan 2008, but see e.g. Sjursen 2002, Deitelhoff 2009, Riddervold 2011, Rosén 2015). Moreover, the approach to arguing in this article is not as "truth-seeking" where actors reach a "reasoned consensus" about the appropriate role of the EP (Rittberger 2005: 59). Rather, actors are not required to have a particular motivation in order for interaction to qualify as communicative. Nor does a reasoned consensus need to be the outcome in order to say that arguments have had an effect. It suffices that actors behave in accordance with arguments they hold to be mutually acceptable, "not necessarily ones that they completely endorse or find maximally advantageous" (Fung and Wright 2003: 17). 
Employing a definition of arguing that is more concerned with interaction, and less with motivation, makes it more relevant to studies of political processes.

Thirdly, why were the arguments of the EP particularly effective during the Convention? Risse and Kleine (2010: 713) highlight uncertainty in connection to role identities and a transparent negotiation setting. I would argue that this article shows how uncertainty and/or disagreement about the principles that should guide reform can be conducive to effectual arguing. Institutional approaches have demonstrated how the Convention-method fostered reason-giving, because the aim was to reach consensus without recourse to voting (Beach 2007). This places a higher demand on actors to explain their positions. At the same time, as this article has shown, because the Convention debated constitutional principles, relying on existing institutional norms also had to be justified.

Proponents of a rhetorical action perspective argue that coherence - either with internal or international norms that are held to be legitimate - is favourable to the success of a rhetorical strategy (Schimmelfennig et al. 2006). Not to award norms with independent impact, and still claim that legitimacy is one of the factors likely to make normative argumentation more effective, I would argue, is contradictory. From a communicative perspective, the issue is not whether an argument is coherent with existing norm-sets, but to what extent the parallel drawn, i.e. the argument about consistency, is accepted as valid. Thus, even if the principle of parliamentary representation has become fundamental to the EU, it will be put to the test again, and will have to be justified yet again to continue to constitute the core of Union level democracy. 
Biographical note: Guri Rosén is Postdoctoral Fellow at ARENA Centre for European Studies University of Oslo.

Address for correspondence: Guri Rosén, ARENA Centre for European Studies University of Oslo. P.O. Box, 1143 Blindern, 0318 Oslo, Norway. E-mail: guri.rosen@arena.uio.no.

\section{ACKNOWLEDGEMENTS}

I am very grateful for the invaluable input and inspiration provided by Helene Sjursen during the process of writing this article. In addition, I would like to thank the three anonymous reviewers for their constructive and helpful feedback. The research for this article has been funded by a PhD Fellowship Grant from the Norwegian Ministry of Defence as well as the Norwegian Research Council through a FRIPRO Mobility Grant, contract number: 240845.

\section{NOTES}

(1) Agreements with legislative implications require EP's consent (Article 227(7) TFEU) (Krajeweski 2005)

(2) I want to thank one anynomous reviewers for highlighting this point.

(3) Rittberger (2005: 102) also concluded that argumentative processes were the reason for the intitial creation of the Parliamentary Assembly. 
(4) All Convention documents are referred to as CONV/NUMBER, and can be accessed through http://ec.europa.eu/dorie/result.do.

(5) In person and via telephone.

(6) The role of the Convention's Working Groups was to prepare the debates on specific subjects, trying to find points of consensus and present these to the plenary for discussion.

(7) For verbatim records, see:

http://www.europarl.europa.eu/Europe2004/index_en.htm

(8) Suggested amendment: http://european-

convention.europa.eu/docs/Treaty/pdf/866/Art\%20III\%20212\%20Hain\%20E

N.pdf

(9) Suggested amendment: http://european-

convention.europa.eu/docs/Treaty/pdf/866/Art24Tiilikainen\%20EN.pdf

(10) As quoted above, Hain (UK) referred to the worry that the proposed reforms could change the "distribution of internal competences within the EU"(WG VII 2002d).

(11) Suggested amendment: http://european-

convention.europa.eu/docs/Treaty/pdf/866/Art\%20III\%20212\%20Hain\%20E

N.pdf

(12) Prior to the Lisbon Treaty, the consent procedure was termed the assent procedure. 
(13) National governments only had one (Normann 2003).

\section{REFERENCES}

Beach, D. (2007) 'The European Parliament in the 2000 IGC and the Constitutional Treaty negotiations: from loser to winner', Journal of European Public Policy 14(8): 1271-1292.

Benedetto, G. and S. Hix (2007) 'Explaining the European Parliament's gains in the EU Constitution', The Review of International Organizations (2): 115129.

Bennett, A. and Checkel, J. (2014) Process-Tracing Cambridge: Cambridge University Press

Bürgin, A. (2007) Die Legitimität der EU. Normative Standards als Verhandlungsressource im Verfassungskonvent Baden-Baden: Nomos.

Commission (2003) 'European Convention and the Inter-governmental Conference. Position of the United Kingdom', Internal note, 28 August.

Deitelhoff, N. (2009) 'The Discursive Process of Legalization: Charting Islands of Persuasion in the ICC Case', International Organization 33(1): 33-65.

Eriksen, E. O. (1999) 'Towards a Logic of Justification. On the Possibility of PostNational Solidarity', in Egeberg, M. and P. Lægreid (eds), Organizing political institutions. Essays for Johan P. Olsen, Oslo: Scandinavian University Press.

Eriksen, E. O. and Fossum, J. E. (2012) 'Representation through Deliberation - the European Case', Constellations 19(2): 325-339. 
European Council (2001) 'Presidency Conclusions European Council meeting in Laeken 14 and 15 December 2001'.

European Parliament (2001) Report on the Treaty of Nice and the future of the European Union, A5-0168/2001, 31 May.

Farrell, H. and A. Héritier (2003) 'Institutions Under Codecision: Continuous Constitution-Building in Europe', Governance 16(4): 577-600.

Fung, A. and E. O. Wright (2003) 'Thinking about Empowered Participatory Governance', in Fung, A. and E. O. Wright (eds), Deepening Democracy. Institutional Innovation in Empowered Participatory Governance, London: Verso, pp. 3-40.

Goetze, S. and B. Rittberger (2010) 'A matter of habit? The sociological foundations of empowering the European Parliament.', Comparative European Politics 8(1): 37-54.

Habermas, J. (1996) Between Facts and Norms: Contributions to a discourse theory of law and democracy Cambridge: MIT Press.

Krajewski, M. (2005) 'External Trade Policy and the Constitutional Treaty: Towards a federal and a more democratic common commercial policy', Common Market Law Review, 42: 91-127.

Magnette, P. and K. Nicolaïdis (2004) 'The European Convention: Bargaining in the Shadow of Rhetoric', West European Politics 27(3): 381-404.

Meunier, S. (2003) 'Trade Policy and Political Legitimacy in the European Union', Comparative European Politics,(1): 67-90.

Niemann, A. (2011) 'Conceptualising Common Commercial Policy Treaty revision: explaining stagnancy and dynamics from the Amsterdam IGC to 
the Treaty of Lisbon', European Integration online Papers (EIoP), 6/16, http://eiop.or.at/eiop/texte/2011-006a.htm.

Norman, P. (2003) The Accidental Constitution: The Story of the European Convention, Brussels: Eurocomment.

Riddervold, M. (2011) 'From reason-giving to collective action: Argument-based learning and European integration'. Cooperation and Conflict 46(4), p. 563- 580.

Risse, T. (2000) 'Let's Argue!: Communicative Action in World Politics', International Organization 1: 1-39.

Risse, T. and M. Kleine (2010) 'Deliberation in negotiations', Journal of European Public Policy 17(5): 708-726.

Rittberger, B. (2005) Building Europe's Parliament. Democratic Representation Beyond the Nation-State, Oxford: Oxford University Press.

Rittberger, B. (2012) 'Institutionalizing Representative Democracy in the European Union: The Case of the European Parliament', Journal of Common Market Studies 50(s1): 18-37.

Rittberger, B. and F. Schimmelfennig (2006) 'Explaining the constitutionalization of the European Union', Journal of European Public Policy 13(8): 11481167.

Roederer-Rynning, C. and F. Schimmelfennig (2013) 'Bringing codecision to agriculture: a hard case of parliamentarization', Journal of European Public Policy 19(7): 951-968.

Rosén, G. (2015) 'EU Confidential: The European Parliament's Involvement in EU Security and Defence Policy', Journal of Common Market Studies 53(2): 383-398. 
Rosén, G. (2016) 'A match made in heaven? explaining patterns of cooperation between the Commission and the European Parliament', Journal of European Integration 38(4): 409-424.

Schimmelfennig, F. (2001) 'The Community Trap: Liberal Norms, Rhetorical Action, and the Eastern Enlargement of the European Union', International Organization 55(1): 47-80.

Schimmelfennig, F. (2003) 'Strategic Action in A Community Environment: The Decision to Enlarge the European Union to the East', Comparative Political Studies 36(1/2): 156-183.

Schneiderhan, E. and S. Khan (2008) 'Reasons and inclusion: The foundation of deliberation.', Sociological Theory 26: 1-24.

Sjursen, H. (2002) 'Why Expand? The Question of Legitimacy and Justification in the EU's Enlargement Policy', Journal of Common Market Studies 40(3): 491-513.

Vanhoonacker, S. (2011) 'The Institutional Framework', in Hill, C. and M. Smith (eds), International Relations and the European Union, 2nd, Oxford: Oxford University Press, pp. 75-100.

Woolcock, S. (2008) 'The potential impact of the Lisbon Treaty on European Union External trade Policy', European Policy Analysis, 8, SIEPS.

Working Group VII External Action (2002a) 'Working document - WD 10', $15 / 10 / 02$.

- $\quad$ (2002b) 'Preliminary draft final report - Working Document 21', 08/11/02.

- $\quad$ (2002c) 'Working document 22', 08/11/02.

- $\quad$ (2002d) 'Working document 40', 19/11/02. 
- $\quad$ (2002d) 'Working document 21 REV1', 22/11/02

- $\quad$ (2002e) 'Working document 21 REV3', 09/12/02. 